\title{
Reflexiones críticas en torno a la STC 61/1997, de 20 de marzo, sobre la Ley del Suelo de 1992 (Cuestiones pendientes de resolución y problemas derivados de la interpretación del TC sobre la cláusula de supletoriedad del Derecho estatal)
}

\author{
María Pardo Álvarez \\ Departamento de Derecho Administrativo \\ Universidad de Valladolid
}

Sumario: I. INTRODUCCIÓN: APROXIMACIÓN AL CONFUSO MARCO LEGAL RESULTANTE DE LA SENTENCIA. II. CUESTIONES IMPUGNADAS Y NO RESUELTAS POR EL FALLO DEL TRIBUNAL. A) El objeto del recurso: impugnaciones competenciales, materiales y formales. B) Problemas sustantivos pendientes de resolución. 1. La regulación de la propiedad sobre el suelo en relación con los artículos 14,33 y $38 \mathrm{CE}$. 2. El porqué de su exclusión del fallo: la discutible caducidad de los recursos contra la Ley de 1990. 3. Vías abiertas para su planteamiento: a) La cuestión de inconstitucionalidad. b) La cuestión interna o autocuestión de inconstitucionalidad. C) Impugnaciones formales no competenciales pendientes de resolución. III. SUPLETORIEDAD DEL DERECHO URBANÍSTICO ESTATAL: PROBLEMAS DE LA DISCUTIBLE LIMITACIÓN JURISPRUDENCIAL DE LA CLÁUSULA DEL ARTÍCULO 149.3 CE.

\section{INTRODUCCIÓN: APROXIMACIÓN AL CONFUSO MARCO LEGAL RESULTANTE DE LA SENTENCIA}

El 20 de marzo de 1997 el Pleno del Tribunal Constitucional resolvió por Sentencia 61/1997 (BOE de 25 de abril) los nueve recursos de inconstitucionalidad que en 1990 y 1992 interpusieron diferentes Comunidades Autónomas contra la nueva legislación del suelo estatal.

La Ley 8/1990, de 25 de julio, sobre reforma del Régimen Urbanístico y Valoraciones del Suelo (en adelante LS90), fue objeto de impugnación por el Parlamento de Navarra, el Consejo de Gobierno de la Diputación Regional de Cantabria, el Consejo Ejecutivo de la Generalidad de Cataluña, la Diputación General de Aragón, la Junta de Castilla y León, y el Gobierno de Canarias ${ }^{1}$.

\footnotetext{
1 Recursos de inconstitucionalidad núms. 2477/90, 2479/90, 2481/90, 2486/90, 2487/90 y 2488/90 acumulados por Auto del Pleno del Tribunal Constitucional de 15 de enero de 1991.
} 
Posteriormente, el Texto Refundido de la Ley sobre Régimen del Suelo y Ordenación Urbana aprobado por Real Decreto Legislativo 1/1992, de 26 de junio (en adelante TR92), fue objeto de tres recursos de inconstitucionalidad presentados por el Consejo de Gobierno de la Comunidad Autónoma de las Islas Baleares, la Diputación General de Aragón y el Consejo Ejecutivo de la Generalidad de Cataluña ${ }^{2}$.

Recaída casi cinco años más tarde de la interposición de los últimos recursos presentados y siete de los seis primeros, esta sentencia ha generado en la legislación urbanística española un inevitable clima de desconcierto y de confusión. La incertidumbre que hasta su resolución pesaba sobre nuestro sistema estatal de ordenación urbanística se ha visto paradójicamente incrementada tras la publicación de este fallo. Así, aunque haya servido para clarificar, con mayor o menor acierto, los ámbitos competenciales de actuación sobre este sector de los entes públicos territoriales en litigio, su aplicación inmediata ha originado una situación marcada nuevamente por la inseguridad. La estimación parcial de algunos de los recursos presentados ha supuesto la eliminación, total o parcial, de aproximadamente las dos terceras partes del TR92, la reviviscencia de un número indeterminado e impreciso de preceptos del Texto Refundido de la Ley sobre Régimen del Suelo y Ordenación Urbana, de 9 de abril de 1976 (en adelante, TR76), así como de los Reales Decretos-Leyes 3/1980 y 16/1981, sobre creación de suelo y agilización de la gestión urbanística y sobre adaptación de Planes Generales de Ordenación Urbana, respectivamente ${ }^{3}$. De este modo, la ejecución de la sentencia ha vuelto a generar una situación similar a la existente tras la aprobación de la LS90: no existe certeza en torno a cuáles son las disposiciones estatales vigentes en materia de suelo y ordenación urba-

2 Recursos de inconstitucionalidad núms. 2337/92, 2341/92 y 2342/92 acumulados por Auto del Pleno del Tribunal Constitucional de 9 de diciembre de 1992.

3 No es fácil precisar el número exacto de artículos del TR92 que han recobrado su vigencia. Los dos primeros apartados del fallo contienen una relación de más de cien artículos de este texto que son declarados nulos e inconstitucionales, bien en su totalidad, bien en alguno de sus apartados o incluso sólo en alguno de sus incisos.

Menos sencillo resulta aún determinar qué preceptos del TR76 vuelven a estar nuevamente vigentes. Conforme se desprende de este fallo, sus preceptos sólo serán aplicables «en la medida en que dichas disposiciones no se extiendan a materias sobre las que el Estado no ostente competencias, y sin perjuicio del efecto derogatorio tácito que puedan desplegar las disposiciones del TR92 dictadas por el Estado en el marco de sus competencias» (f.j. 12). Así, todavía queda por interpretar cuáles de sus preceptos no invaden la competencia autonómica sobre el urbanismo, tal y como ha sido delimitada en esta sentencia, y, dentro de éstos, cuáles no son aplicables por regular aspectos sobre los que el TR92 sigue desplegando sus efectos.

Respecto de los citados Reales Decretos-Leyes, ni siquiera está claro que puedan ser aplicables, pues sus preceptos fueron incorporados al TR92 con el carácter de legislación supletoria y, como tales, declarados nulos por la sentencia. Vid. A. ORTEGA GARCLA, Derecho Urbanístico y la sentencia del Tribunal Constitucional, Montecorvo, Madrid, 1997, págs. 19-20. 
na y, como entonces, existe un conjunto de disposiciones normativas atinentes a una misma materia ubicadas en una variedad dispersa de normas.

La situación se complica aún más si tenemos en cuenta que este fallo no sólo afecta a la normativa impugnada, sino también al contenido de disposiciones dictadas desde instancias estatales en fechas posteriores a la aprobación del TR92. En concreto, las anulaciones contenidas en la sentencia cuestionan la validez del Real Decreto 304/1993, de 26 de febrero, por el que se aprueba la tabla de vigencias de los Reglamentos urbanísticos, al perder éste gran parte de la base legal justificadora de sus propias derogaciones ${ }^{4}$; así como, implícitamente y sobre todo, la validez de la Ley $7 / 1997$, de 14 de abril, de medidas liberalizadoras en materia de suelo y Colegios profesionales, recientemente impugnada ante el Tribunal Constitucional ${ }^{5}$.

\footnotetext{
4 Este Real Decreto se elaboró tardíamente en cumplimiento del compromiso que el propio Gobierno adquirió al aprobar el TR92 (Disposición Final Única, punto 4), de determinar los preceptos aún vigentes de los Reglamentos de Planeamiento, Gestión Urbanística, Disciplina Urbanística, Edificación Forzosa y Registro Municipal de Solares, y Reparcelaciones aprobados entre 1964 y 1978. Su contenido carece sensu stricto de regulación ex novo ya que los preceptos reglamentarios que proclama derogados lo estaban ya tras la entrada en vigor del TR92 limitándose, por tanto, a clarificar en aras de la seguridad jurídica tales derogaciones. Pero hoy, tras la sentencia, muchos de los preceptos reglamentarios dictados en desarrollo de las previsiones del TR76 y derogados por este Real Decreto, han vuelto a recobrar su función y aplicabilidad tras la comentada reviviscencia parcial de la norma legal objeto de desarrollo: el TR76. En relación con los efectos de la sentencia sobre este Real Decreto vid. J. L. MARTINEZ LOPEZ-MUÑIZ, Dictamen sobre la sentencia del Tribunal Constitucional de 20 de marzo de 1997 sobre la Ley del Suelo de 1992, pro manuscrito, Valladolid, mayo de 1997, pág. 24; y F. FONSECA FE. RRANDIS et al., Legislación del suelo: análisis comparativo. Incidencia de la STC 61/1997 (Dir. por A. E. DE Asis RoIG), La Ley-Actualidad, Madrid, 1997, págs. 42-43.
}

5 Esta Ley tiene su origen en el Real Decreto-Ley 5/1996, de 7 de junio, que, tras ser convalidado por el Congreso de los Diputados, fue tramitado como proyecto de ley por el procedimiento de urgencia $e x$ artículo 86.3 CE.

Contra ella se interpuso, el pasado 22 de julio, el recurso de inconstitucionalidad núm. 3148/1997, promovido por el Gobierno de la Junta de Comunidades de Castilla-La Mancha. El recurso se dirige contra los preceptos de esta norma de contenido urbanístico al encontrarse, en su mayoría, directamente afectados por la doctrina sentada por esta sentencia. Así, por un lado, contiene una serie de preceptos de aplicación supletoria (artículos 1, 3, 4 y Disposición Transitoria única) que chocan frontalmente con la nueva doctrina del Alto Tribunal sobre la cláusula de supletoriedad (vid. f.j. 12). Por otro, contiene un artículo de aplicación básica relativo al porcentaje de aprovechamiento apropiable por el titular del terreno (artículo 2) que se ha visto igualmente afectado por la interpretación del Tribunal Constitucional en torno a la competencia para fijar tal porcentaje (vid. ff.jj. 17 y 24) y cuyo contenido deviene en gran medida de imposible aplicación, bien por haber desaparecido aquellos preceptos del TR92 que completaban su contenido, bien por no tener sus previsiones reflejo en los artículos nuevamente vigentes del TR76. Para un análisis más detallado de esta cuestión vid. J. L. MARTINEZ LOPEZ-MuÑIZ, Dictamen..., cit. págs. 16-19 y 55-72; A. ORTEGa GaRCla, Derecho Urbanístico..., cit., págs. 40-47; F. FonSECA FERRANDIS, Legislación del suelo..., cit., págs. 44-45; J. L. GONZÁLEZ-BERENGUER Y URRUTIA, La Ley del Suelo después de la Sentencia del TC de 20 de marzo de 1997, Civitas, Madrid, 1997, págs. 173-176; y E. Porto Rey, «Comentarios prácticos a la Ley 7/97, de medidas liberalizadoras en materia de suelo, tras la STC sobre la LS92", RDU, núm. 153, 1997, págs. 129 y ss. 
De igual manera, este pronunciamiento del Tribunal Constitucional ha generado un cierto desorden en el ámbito de la normativa urbanística autonómica. Así, algunas Comunidades Autónomas han optado por declarar total o parcialmente aplicable a su ámbito territorial el Derecho estatal vigente con anterioridad a la publicación de la sentencia 61/1997 sin tener en cuenta suficientemente, quizás, que tal práctica sólo podría hacerse en tanto en cuanto el legislador estatal realizase correctamente las habilitaciones oportunas, supuesto que no siempre ocurre ${ }^{6}$. Otras, se encuentran en proceso de aprobación de una normativa propia porque carecían de ella, o en proceso de adaptación de la ya vigente al nuevo régimen legal ${ }^{\text {? }}$.

Ante semejante panorama, en los escasos meses que han transcurrido desde la publicación de este fallo, la actualidad urbanística ha estado marcada por el afán de clarificar y determinar el marco legal que al día de hoy, y quizás no por mucho tiempo ${ }^{8}$, regula este sector del ordenamiento jurídico.

\footnotetext{
6 Dos han sido, por el momento, las Comunidades Autónomas que han procedido en este sentido: a) la Comunidad Autónoma de Cantabria que, por Ley 1/1997, de 25 de abril, de medidas urgentes en materia de régimen del suelo y ordenación urbana (BOC de 25 de abril), ha asumido, como propio y aplicable en lo no previsto por su propia normativa autonómica, el Derecho estatal que estaba vigente con anterioridad a la publicación de esta sentencia aun cuando se trate de preceptos que, conforme al criterio del Tribunal Constitucional, invadian sus competencias exclusivas; y b) la Comunidad Autónoma de Andalucía que, en similares términos, ha asumido como Derecho propio parte de los artículos del TR92 declarados inconstitucionales según los términos establecidos en su Ley $1 / 1997$, de 18 de junio, por la que se adoptan con carácter urgente y transitorio disposiciones en materia de régimen de suelo y ordenación urbana (BOE de 7 de julio).
}

7 Castilla-La Mancha, una de las Comunidades Autónomas carente de legislación propia en materia de urbanismo, ha aprobado el pasado 10 de julio la Ley 5/1997 de medidas urgentes en materia de suelo y ordenación urbana. De igual forma, la Comunidad Autónoma del País Vasco ha dictado la Ley 3/1997, de 25 de abril, por la que se determina la participación de la comunidad en las plusvalías generadas por la acción urbanística en la Comunidad del País Vasco. También tenemos conocimiento de que en la Comunidad Autónoma de Castilla y León tras la aprobación, el pasado 30 de mayo, de una Circular sobre criterios para la aplicación del régimen jurídico urbanístico tras la STC 6I/1997, de 20 de mayo, cuenta en la actualidad con un proyecto de Ley de medidas transitorias en materia de urbanismo y con un anteproyecto de Ley de ordenación del territorio. Por su parte, en la Comunidad Autónoma de Madrid existe también un proyecto de Ley de medidas urgentes en materia de suelo y urbanismo aprobado por la Asamblea de Madrid el 10 de julio de 1997.

8 El pasado 23 de mayo el Consejo de Ministros remitió a las Cortes Generales por el procedimiento de urgencia (BOCG de 9 de junio de 1997, Serie A, núm. 66-1) un proyecto de Ley sobre Régimen del Suelo y Valoraciones con el propósito de acomodar la normativa urbanística estatal a la reciente doctrina del Tribunal Constitucional. Sobre el citado proyecto algunos autores han manifestado ya su total desacuerdo hacia las modificaciones que con su aprobación se introducirían en nuestro actual régimen jurídico-urbanístico estatal. Entre ellos destaca la alarmante visión del profesor ParaDA VAzQUEZ, quien pronostica la hecatombe más absoluta para nuestro sistema urbanístico de ser finalmente aprobado por las Cortes este proyecto de Ley irracionalmente «liberalizador» del régimen jurídico del suelo (Vid. Diario $A B C$ de 19 de junio de 1997, "Si Ildefonso Cerdá levantara la cabeza»). Pese a tales consideraciones, a nuestro juicio, del contenido del citado proyecto no se desprende que vaya a producirse un giro radical en la regulación jurídica de la materia. Como en anteriores reformas, siguen respetándose los 
REFLEXIONES CRITICAS EN TORNO A LA STC 61/1997, ...

En las siguientes líneas queremos detenernos en el análisis de otros problemas relacionados igualmente con esta sentencia, que no tienen quizás menor relevancia que los indicados. En concreto, vamos a referirnos a dos cuestiones. En primer lugar, analizaremos la situación de pendencia a que sigue sujeta nuestra normativa urbanística estatal ante la falta de resolución por el Tribunal Constitucional de ciertas impugnaciones presentadas por los recurrentes. Posteriormente, nos detendremos en el estudio de las repercusiones que para este sector del ordenamiento jurídico supone la aplicación de la doctrina de este fallo sobre la cláusula de supletoriedad del Derecho estatal sobre el autonómico.

Ambos extremos cuestionan por igual la corrección o el acierto de algunos aspectos del proceder y del parecer del Tribunal Constitucional.

\section{CUESTIONES IMPUGNADAS Y NO RESUELTAS POR EL FALLO DEL TRIBUNAL}

\section{A) El objeto del recurso: impugnaciones competenciales, materiales y formales}

El núcleo central de las impugnaciones presentadas contra estas leyes estuvo básicamente - aunque no exclusivamente - en problemas de índole competencial. A lo largo de los 42 fundamentos jurídicos que constituyen esta extensa

principios básicos que desde 1956, año en que se aprobó la primera legislación propiamente urbanística, hasta la actualidad han caracterizado el marco legal del urbanismo. Así, seguirá correspondiendo al poder público la dirección última del proceso urbanístico (artículo 4.1); los planes continuarán constituyendo el instrumento y la base fundamental de toda la ordenación urbana, así como el acto jurídico que, gracias a la genérica remisión de la Ley, determine el contenido del derecho de propiedad (artículo 2); la clasificación y la calificación seguirán manteniéndose como las técnicas de atribución a la propiedad del suelo de contenidos de aprovechamiento urbanístico (capítulo I); y, en fin, la propiedad del suelo continuará sujeta a un estatuto diferente en función de la concreta clasificación conferida por el plan a cada porción de terreno.

La única modificación relevante del presente proyecto de Ley estaría en la posible desaparición de lo que constituyó una de las principales innovaciones de la reforma de la Ley del Suelo de 1990. Como veremos más adelante, desde la aprobación de la LS90, el ius aedificandi -o derecho a edificar- quedó desgajado del derecho de propiedad sobre el suelo de forma que, de facultad inherente al mismo, pasó a convertirse en facultad «susceptible de adquisición», como si de una "concesión» se tratara. Frente a esta regulación, el proyecto devolvería al contenido de la propiedad una de sus facultades más inherentes, la de urbanizar o edificar en forma urbana, aunque, eso sí, ejercida dentro de los límites y con el cumplimiento de los deberes establecidos al respecto (artículo 2.1).

En definitiva, el citado proyecto no responderia tanto a la implantación de un nuevo modelo de regulación de la utilización del suelo, cuanto a la adecuación del sistema ya existente al marco competencial perteneciente al legislador estatal conforme se desprende de la doctrina resultante de la STC 61/1997. Sobre el citado proyecto vid. J. E. SORIANo, "La liberalización del suelo», en El urbanismo hoy. Reflexiones a propósito de la STC 6I/1997 y el proyecto de nueva Ley estatal. (Coord. L. PAREJO ALFONSO), Instituto Pascual Madoz, Madrid, 1997, págs. 19-54. 
sentencia, el Tribunal Constitucional se pronuncia en torno a la supuesta invasión por el legislador estatal del ámbito competencial de las Comunidades Autónomas en materia de urbanismo. Los entes autonómicos recurrentes impugnaron ambas normativas por considerar que el Estado no estaba habilitado para legislar con el alcance con que lo hizo sobre una materia que la Constitución asigna potencialmente de modo expreso a los entes autonómicos (artículo 148.1.3. CE) y que todos los Estatutos de Autonomía les reservan en «exclusiva»?

Así, el origen de la controversia surge cuando, en 1990, el legislador estatal, aun reconociendo su inicial «incompetencia» para legislar en concreto sobre el urbanismo ${ }^{10}$, elaboró y dictó la citada LS90, atribuyendo a sus preceptos uno u otro carácter - plenos, básicos o supletorios- ${ }^{11}$ en función del aspecto urbanístico objeto de regulación (planeamiento, régimen urbanístico de la propiedad del suelo, disciplina urbanística, etc...) y del título competencial por el que se consideraba legitimado para regularlo ${ }^{12}$.

9 Cfr. con los correspondientes Estatutos de Autonomía en los artículos siguientes: Andalucía, artículo 13.8; Aragón, artículo 35.1.g) ; Asturias, artículo 10.1.b); Baleares, artículo 10.3; Canarias, artículo 30.15; Cantabria, artículo 22.3; Castilla y León, artículo 26.3; Castilla-La Mancha, artículo 31.b); Cataluña, artículo 9.9; Extremadura, artículo 7.2; Galicia, artículo 27.3; La Rioja, artículo 8.8; Madrid, artículo 26.3; Murcia, artículo 10.1.b); Navarra, artículo 44.1; País Vasco, artículo 10.31; y Valencia, artículo 31.9 .

10 En la Exposición de Motivos de la LS90 el legislador estatal hizo expresa referencia a esta nueva situación surgida tras la aprobación de la Constitución:

«La delimitación constitucional de competencias parece impedir que el Estado apruebe una nueva Ley sobre régimen del suelo y ordenación urbana con el mismo o similar contenido al del texto refundido actualmente vigente, con pretensión de aplicación plena, ya que su regulación supondría una manifiesta invasión de las competencias autonómicas en materia de ordenación del territorio y urbanismo. Pero tampoco las Comunidades Autónomas están facultadas para establecer una normativa urbanística de alcance y contenido tan amplio como el de la Ley vigente, porque ello chocaria con las competencias que al Estado atribuye el propio texto constitucional» (cursiva nuestra). Cfr. el apartado II, párrafo primero.

11 Vid. la Disposición Final Primera, apartados 1, 2 y 3 de la LS90.

12 Por una parte, se invocaron por el Estado las reglas 8." y 18." del artículo 149.1. CE, es decir, sus competencias exclusivas en materia de legislación civil y bases del régimen jurídico de las Administraciones Públicas, procedimiento administrativo común y responsabilidad de la Administración, para regular, con el carácter de legislación plena, determinadas materias con incidencia sobre el urbanismo (fundamentalmente, las relativas a valoraciones, expropiaciones y justiprecio expropiatorio).

En otros casos, el Estado, amparándose en las reglas 1." 8.", 18." y 23." del 149.1 CE, dotaba a sus preceptos del alcance de legislación básica, pudiendo así las Comunidades Autónomas ejercitar su potestad legislativa de desarrollo. A este carácter respondían la mayoría de preceptos no plenos, esto es, la regulación del régimen urbanístico de la propiedad del suelo y la fijación de los supuestos indemnizatorios, principalmente.

Finalmente, el resto de disposiciones sólo tenían pretensión de aplicación supletoria y, por ello, únicamente aplicables, bien en defecto de regulación específica por las Comunidades Autónomas, bien ante posibles lagunas en aquellas que sí la tuvieran. Para esta regulación se invocó la cláusula de supletoriedad del Derecho estatal sobre el autonómico, ínsita en el párrafo 3 del artículo $149 \mathrm{CE}$. 
El TR92, partiendo de esta triple naturaleza con que se dictó la LS90, trasladó este mismo esquema a todo su articulado. De este modo, aquellos preceptos ya calificados por la LS90 fueron refundidos por lo general con idéntico alcance y aquellos otros procedentes del TR76 y carentes de cualquier determinación en torno al alcance de su aplicación por ser anteriores al texto constitucional, recibieron semejante calificación diferenciada —operación ésta que ha suscitado cierta polémica- ${ }^{13}$.

Fue esta calificación otorgada por el legislador estatal lo que originó el principal argumento para la interposición de los citados recursos de inconstitucionalidad, primero contra la LS90 y, posteriormente, contra el TR92.

Pero, junto a esta impugnación central, existieron otras que, sin embargo, no han sido atendidas por el Tribunal Constitucional. Como veremos a continuación, han sido dos las cuestiones que, pese a su relevancia, no han obtenido respuesta del Alto Tribunal: por un lado, la posible violación por la legislación estatal impugnada de derechos y principios constitucionales (impugnaciones de carácter material) y, por otro, la posible extralimitación del Gobierno refundidor en el ejercicio de la delegación legislativa (impugnaciones de carácter formal).

\section{B) Problemas sustantivos pendientes de resolución}

\section{La regulación de la propiedad sobre el suelo en relación con los artículos 14, 33 y $38 \mathrm{CE}$}

Como decimos, entre las impugnaciones presentadas contra la LS90 hubo algunas que, junto a los aludidos motivos de inconstitucionalidad competencial, alegaron otros de carácter material ${ }^{14}$.

13 Vid. F. Perales Madueño, «El nuevo Texto Refundido de la Ley del Suelo y Ordenación Urbana del Estado", RDU, núm. 129, 1992, págs. 38 a 42; y Dictamen del Consejo de Estado núm. 648/92, de 11 de junio, Sección 6.", número de marginal 11 de la Recopilación de Doctrina Legal, BOE, Madrid, 1992, considerando I, punto 2, pág. 27.

14 Es necesario recordar aquí que la genérica previsión del artículo 162.1.a) CE por la que se incluye a las Comunidades Autónomas entre los sujetos legitimados para interponer recursos de inconstitucionalidad, fue concretada por la LOTC en un sentido muy restrictivo. Así, su artículo 32.2 introdujo dos condiciones no previstas constitucionalmente y claramente limitadoras de la legitimación de las Comunidades Autónomas para promover esta clase de procesos: 1) que la norma impugnada fuese una ley del Estado y 2) que pueda «afectar a su propio ámbito de autonomía».

Dejando a un lado el primero de los límites apuntados, importa conocer que la jurisprudencia del Tribunal Constitucional ha ido flexibilizando el tenor literal del segundo de ellos. Así, frente a iniciales pronunciamientos en los que exigía una rigurosa implicación conflictual en la impugnación (STC 25/1981, de 14 de julio, f.j. 5), el Tribunal Constitucional atenuó en sucesivos pronunciamientos este requisito. Es con la importante Sentencia 84/1982, de 23 de diciembre, cuando se admite por primera vez y con ca- 
En concreto, el Consejo de Gobierno de la Diputación Regional de Cantabria recurrió el artificioso sistema de adquisición escalonada de facultades del derecho de propiedad diseñado por esta norma, al estimar que los plazos preclusivos que regían su adquisición y la dura sanción que imponía en caso de incumplimiento atentaban contra el principio de libertad de empresa reconocido en el artículo $38 \mathrm{CE}^{15}$.

A estas impugnaciones materiales se sumó el Gobierno de Canarias por un doble motivo: a) por violación del derecho a la igualdad recogido en el artículo $14 \mathrm{CE}$ en que incurría el trato discriminatorio que la LS90 otorgaba a los propietarios de suelo urbano y urbanizable en función de que el municipio en que se encontrasen ubicados sus terrenos contase o no con Plan General en vigor o Normas Subsidiarias u otro instrumento de planeamiento; b) por constituir la LS90, en su conjunto, una violación del artículo $33 \mathrm{CE}$ al delimitar el contenido de la propiedad remitiéndolo al grado de ejecución del planeamiento y al establecer un sistema sancionatorio por incumplimiento de los deberes urbanísticos consistente en la privación misma de tal derecho de propiedad o de parte de él ${ }^{16}$.

Se trata de impugnaciones que, pese a su genérica formulación, cuestionaban la constitucionalidad del núcleo esencial de la nueva legislación urbanística, esto es, el nuevo estatuto que la LS90 confirió a la propiedad del suelo ${ }^{17}$.

rácter general, que la interposición de un recurso de inconstitucionalidad por parte de un ente autonómico no queda limitado a la defensa de sus propias competencias. En su fundamento jurídico primero, el Tribunal Constitucional consideró que la identificación del «ámbito de autonomía» con la suma de las competencias asignadas a las Comunidades Autónomas no era aceptable a la luz de la finalidad perseguida por el recurso de inconstitucionalidad, pues éste no persigue la mera defensa de las competencias de la Comunidad recurrente, sino «la depuración objetiva del ordenamiento jurídico». Siguiendo la línea abierta por este fallo, las SSTC 63/1986, de 21 de mayo, y 99/1986, de 11 de julio, ampliaron la legitimación procesal de las Comunidades Autónomas dejándola abierta a prácticamente todos los supuestos con el único requisito de que la norma estatal impugnada regule una materia en la cual el ente autonómico posea competencias propias aunque «distintas de las del Estado», sin que sea preciso que la norma estatal incida directamente en el ejercicio de competencias autonómicas. Esta doctrina ha sido mantenida por el Alto Tribunal en Sentencias como la 199/1987, de 16 de diciembre; la 56/1990, de 29 de marzo; o la 62/1990, de 30 de marzo, entre otras.

Para un estudio más detallado de esta cuestión vid. por todos R. CanOSA Usera, Legitimación autonómica en el proceso constitucional, Trivium, Madrid, 1992, págs. 59-86; y A. Allue BuizA, Legitimación de las Comunidades Autónomas en el recurso de inconstitucionalidad, Secretariado de Publicaciones de la Universidad de Valladolid, Valladolid, 1992, págs. 33-45.

Gracias a esta evolución jurisprudencial, las Comunidades Autónomas ahora recurrentes pudieron añadir a los concretos problemas competenciales otros, con ese propósito de «depuración objetiva del ordenamiento» y no de mera defensa de su ámbito de autonomía.

15

Cfr. recurso de inconstitucionalidad núm. 2479/90, letra c).

16

Cfr. recurso de inconstitucionalidad núm. $2488 / 90$, letra e).

17 No es, por eso, enteramente cierto que «ninguno de los recursos de inconstitucionalidad promovidos planteó problema alguno de orden material o sustantivo» (T. R FERNÁNDEZ RODRIGUEZ, «El descon- 
Como se desprende de su Exposición de Motivos, el principal objetivo de esta Ley fue el de «modificar el régimen hasta ahora vigente sobre los derechos y deberes de los propietarios del suelo afectados por el proceso de urbanización y edificación» ${ }^{18}$. Esquemáticamente, esta modificación supuso que, desde su aprobación, sólo la utilización rústica y análogas del terreno integran el contenido inherente al derecho de propiedad sobre el suelo. La urbanización del suelo o su edificación en forma urbana dejan de constituir facultades inherentes al contenido de este derecho para convertirse en facultades o derechos «susceptibles de adquisición» consagrándose, ahora sí, la tan defendida idea por algunos de que el ius aedificandi no forma parte desde la promulgación de la Ley del Suelo de 1956 del contenido del dominio, sino que es una atribución del planeamiento urbanístico ${ }^{19}$. La Ley optó por publificar, por reservar al sector público la titularidad de estas actividades que podrán, en principio, ser directamente ejercidas por la administración pública urbanística, o concederse su gestión a quien esté en condiciones de asumirlas. Pero esta publicatio de las actividades de urbanizar y construir en forma urbana se ha diseñado con el agravante para determinados propietarios (los de suelo urbano y urbanizable) de que quedan obligados, y no facultados, a incorporarse al proceso urbanizador y edificatorio ${ }^{20}$. Y es que, el contenido urbanístico de la propiedad inmobiliaria

certante presente y el imprevisible y preocupante futuro del Derecho Urbanistico español», REDA, núm. 94, 1997, pág. 191); ni que «las Comunidades recurrentes adoptaron una perspectiva puramente formal (competencial), denunciando la invasión de sus competencias, no los criterios materiales que inspiraban la nueva regulación» (A. MENÉNDEZ REXACH, «Las competencias del Estado y de las Comunidades Autónomas sobre el régimen del suelo. Comentario crítico de la STC de 20 de marzo de 1992", $R D U$, núm. 153, 1997, pág. 37).

18

Cfr. apartado II, párrafo segundo.

19 Para un importante sector doctrinal esta sustracción se venía produciendo ya en nuestro Derecho desde la entrada en vigor de la Ley del Suelo de 1956. No era sólo que las facultades relativas a la utilización del suelo no pudieran ejercitarse si no era respetando el elenco de limitaciones positivas - «deberes»- y negativas - «limitaciones»- que para cada tipo de suelo se establecían en la Ley o, por remisión de ésta en el Plan, sino que éstas eran otorgadas por la Administración a través del planeamiento sin que formaran parte del contenido propio del derecho de propiedad. En este sentido, vid. por todos E. Garcla DE EnTERría, «Ley del Suelo y el futuro del Urbanismo», Anuario de Derecho Civil, XI, 1958, pág. 501; y «Actuación pública y actuación privada en el Derecho Urbanístico», REDA, núm. 1, 1974, pág. 86.

Pero en puridad, esto no ocurre, como veremos a continuación, hasta la aprobación de esta LS90. En este sentido, vid. J. M. LOBATO GÓmEZ, «Observaciones críticas sobre el régimen urbanístico de la propiedad del suelo", REALA, núm. 262, 1994, págs. 247-252; J. E. SORIANo GARCí, Hacia la tercera desamortización (Por la reforma de la Ley del Suelo), Marcial Pons, Madrid, 1995, págs. 81-84; y J. L. MARTíNEZ LÓPEZ-MUNizz, «Derecho de propiedad y proyecto de Ley de Reforma de la Ley del Suelo», en Derecho Urbanistico Local, AA.VV., (Coord. J. M. BoquerA OLIVER), Civitas, Madrid, 1992. págs. 63 y ss.

20 Así lo disponía el artículo 8 de esta Ley (hoy 19 del TR92) al prever que «la aprobación del planeamiento preciso según la clase de suelo de que se trate, determina el deber de los propietarios de incorporarse al proceso urbanizador y edificatorio, en las condiciones y en los plazos previstos por el planea- 
es objeto con la aprobación de esta Ley de una «disociación abstracta» ${ }^{21}$, en cuanto se integra mediante la adquisición sucesiva de una serie de derechos (a urbanizar, al aprovechamiento urbanístico, a edificar y a la edificación, artículo 11) que constituyen para los propietarios «auténticas cargas públicas» ${ }^{22}$, en cuanto que tales «derechos» quedan sujetos al cumplimiento de correlativos deberes en sucesivos plazos preclusivos garantizados bajo la amenaza de auténticas expropiaciones sancionadoras ${ }^{23}$. En palabras de SoRIANO GARCía, este nuevo sistema legal - aún vigente - conduce a que «la propiedad, como derecho, haya dejado de existir urbanísticamente, salvo para identificar física y jurídicamente al sujeto destinatario de la normativa urbanística y del Plan» ${ }^{24}$.

Ante esta nueva regulación, parece lógico que los recurrentes anteriormente citados solicitasen un pronunciamiento del Tribunal Constitucional que aclarase la compatibilidad de ésta con la protección constitucional del derecho de propiedad de los ciudadanos en condiciones de igualdad (artículos 33 y $14 \mathrm{CE}$ ). Y es que resulta discutible desde parámetros constitucionales que la imposición a determinados ciudadanos - los propietarios de suelo urbano y urbanizable - de ese conjunto de deberes urbanísticos de obligatorio cumplimiento no constituya un atentado contra el principio de igualdad ante las cargas públicas $^{25}$. Asimismo, plantea interrogantes el trato discriminatorio que a efectos de valoraciones se otorga por esta norma a los propietarios de suelo no urbanizable y urbanizable no programado frente a los propietarios de suelo urbanizable programado ${ }^{26}$. Tratamiento discriminatorio que se mantiene, además, cuando la Administración obtiene terrenos por expropiación para sistemas generales, o para la constitución o ampliación del Patrimonio Municipal del

miento o legislación urbanística aplicable, conforme a lo establecido en esta Ley».

21 Cfr. J. M. LOBato Gómez, «Observaciones críticas...», cit., pág. 249.

22 Cfr. J. L. MARTINEZ LÓPEZ-MuÑIZ, «Derecho de propiedad...», cit., pág. 67.

23 Para corroborarlo, vid. las previsiones de los artículos 14, 18.1, 19.2, 22 y 23 de la LS90 que, como veremos, han pasado al articulado del TR92 siendo aún, en su mayoría, Derecho vigente. Sobre el carácter sancionador de estas expropiaciones vid. J. SUAY RINCóN, «La expropiación por incumplimiento en la nueva Ley del Suelo. Su carácter sancionador y sus consecuencias jurídicas», $R D U$, núm. 123, 1991, págs. 71 y ss., en especial 82-83.

24 Cfr. J. E. Soriano Garcia, Hacia la tercera desamortización..., cit., pág. 81. En semejantes términos, vid. J. L. MARTÍNEZ LOPEZ-MUÑIZ, «Derecho de propiedad...» cit., págs. 94-95.

25 Vid. J. L. MARTINeZ LÓPEZ-MuÑIz, «Derecho de propiedad...», cit., pág. 92.

26 Así, por ejemplo, mientras para los primeros se prevé una tasación de su terreno con arreglo al valor inicial (esto es, aplicando los criterios de las valoraciones catastrales de suelo de naturaleza rústica, sin consideración alguna a su posible utilización urbanística) para los propietarios de suelo urbanizable programado la tasación se calcula agregando al valor inicial el $25 \%$ del coste estimado de su futura urbanización -artículo 66.1 y 2 LS90, hoy 48.1 y 2 del TR92 aún vigente-. 
REFLEXIONES CRITICAS EN TORNO A LA STC 61/1997...

Suelo o de viviendas de protección pública ${ }^{27}$ y 28 . Otro tanto cabría decir en relación con los mecanismos diseñados por la norma para impedir la desigual atribución de los beneficios y cargas del planeamiento entre los propietarios afectados pues, como el propio Preámbulo de esta LS90 reconocía, «ni juegan entre las diversas clases de suelo ni en el seno de cada una de ellas en su totalidad» ${ }^{29}$, sino que sólo tienen aplicación en los terrenos clasificados como suelo urbano y urbanizable ${ }^{30}$. Estas discriminaciones de propietarios en función de la categoría de suelo que les sea atribuida «son demasiadas como para sostener que respetan el principio de igualdad» ${ }^{31}$ y encuentran difícil justificación.

Desde otra perspectiva, los recurrentes solicitaban también el enjuiciamiento de este nuevo régimen de la propiedad del suelo en relación con el respeto a «la libertad de empresa en el marco de la economía de mercado» tal y como re-

planeamiento o legislación urbanística aplicable, conforme a lo establecido en esta Ley».

27 En este caso, los propietarios de suelo urbanizable no programado siguen obteniendo el valor inicial de sus terrenos, mientras que los de suelo urbanizable programado verán valorado su terreno refiriendo a su superficie el 50\% del aprovechamiento tipo del área de reparto. Vid. A. GaLLEGo ANABrTARTE, «Régimen urbanístico de la propiedad del suelo. Valoraciones. Expropiaciones y venta forzosa», Curso sobre el Texto Refundido de la Ley del Suelo de 26 de junio de 1992, Gerencia Municipal de Urbanismo. Ayuntamiento de Madrid, 1993, pág. 17.

28 Hay que tener en cuenta que las referencias al suelo urbanizable programado y no programado deben entenderse en la actualidad desaparecidas tras la supresión por el artículo 1.1 del Real Decreto-Ley 5/1996, de 7 de junio, de medidas liberalizadoras en materia de suelo y colegios profesionales - hoy Ley 7/1997, de 14 de abril, de la misma rúbrica - de ambas categorías que pasan a integrarse en una sola: la del suelo urbanizable. Sin embargo, las referencias anteriormente indicadas aún pueden tener actualidad por cuanto, conforme a la Disposición Transitoria Única de esta norma, «el suelo clasificado como urbanizable no programado en el planeamiento vigente o en tramitación a su entrada en vigor, mantendrá el régimen jurídico previsto en la normativa urbanística anterior».

Para un estudio más extenso de este Decreto-Ley vid. J. GonzÁLEZ PÉREZ, «Medidas liberalizadoras en materia de suelo", en vol. col. Reforma y liberalización económica (Los Decretos Leyes de junio de 1996), Civitas, Madrid, 1997, págs. 43-90.

29 Cfr. apartado III, punto 5 de la Exposición de Motivos de la LS90.

30 A esta cuestión se refirió prontamente T. R. FERNÁNDEZ RODRíGUEZ, en relación con el procedimiento arbitrado por las Leyes de 1956 y 1975 para reducir la desigualdad a que da lugar el planeamiento. Vid. "Reflexiones en torno al principio de igualdad en el ordenamiento urbanístico», $R D U$, núm. 65, 1979, págs. 16-25. A favor vid. PARADA VÁZQUEZ, Derecho Administrativo, cit., págs. 360364; M. R. Alonso lBÁÑEZ, «Consecuencias indemnizatorias de la modificación o revisión del planeamiento en la Ley de Reforma del Régimen Urbanístico.y Valoraciones del Suelo, de 25 de julio de 1990», REALA, núm. 253, 1992, págs. 53-54; y J. M. BOQUERA OLIVER, «La limitación de la propiedad urbanística según la Constitución», en Derecho Urbanístico Local, AA.VV. (Coord. J. M. BoQUERA Olıver), Civitas, Madrid, 1992, págs. 61-62; y J. M. LoвATo GOMEZ, Propiedad privada del suelo y derecho a edificar, Montecorvo, Madrid, 1989, págs. 601-602. En sentido manifiestamente contrario vid. A. Menéndez RexaCH, «La propiedad en la nueva Ley del Suelo», Derecho Privado y Constitución, núm. 3, Centro de Estudios Constitucionales, 1994, págs. 96-100.

Cfr. R. Parada VÁzquez, Derecho Administrativo, cit., pág. 340. 
conoce el artículo 38 de nuestra Constitución. En este sentido, se trataría de determinar si la conversión del propietario por la Ley que comentamos en un colaborador forzoso de la Administración, en un cuasi-concesionario de un servicio público, no impide en gran medida el ejercicio de este derecho ${ }^{32} \mathrm{o}$, como manifiestan algunos, si no atenta directamente contra su contenido ${ }^{33}$. En principio, esta decisión legislativa de publificar las actividades relativas a la urbanización y edificación en forma urbana con la consiguiente restricción de libertades como la de empresa, es perfectamente encuadrable en nuestro sistema constitucional porque el artículo 128.2, segundo inciso, de nuestro texto constitucional ha habilitado al legislador para «reservar al sector público recursos o servicios esenciales». Sin embargo, esta publicatio y esta restricción a la libertad no está exenta de condicionamientos. Así, siguiendo el planteamiento de MARTínez Ló PEZ -MUÑIZ, «en un sistema constitucional basado en el principio pro libertate no debe admitirse que el legislador pueda hacer esa plena publicatio sin alguna razón de interés público proporcionadamente suficiente» ${ }^{34}$. Y en este caso, la duda estriba en si el pretendido fin o propósito perseguido por la norma, en concreto, evitar y controlar «el fuerte incremento del precio del suelo, [...] y su repercusión en los precios finales de las viviendas y, en general en los costes de implantación de actividades económicas" ${ }^{35}$, es un fin de interés público capaz de justificar la medida adoptada, o si existe una desproporción de medios a fines.

De igual manera, implícitamente se planteaba la posible violación de la garantía indemnizatoria prevista por el artículo 33.3 de la Constitución en que in-

32 Como viene afirmando un importante sector doctrinal, la libertad de empresa incluye como parte de su contenido esencial una serie de libertades entre las que se encuentra la libertad de acceso al merca. do. Para el ejercicio de esta libertad se precisa, a su vez, el previo reconocimiento de otros derechos, entre los que figura el derecho de propiedad privada. La propiedad se convierte así en "presupuesto de la libertad de empresa», en su «título y fundamento» por lo que si deja de existir como tal o se convierte, como en este caso, en mera conditio sine qua non para la sucesiva adquisición de un conjunto de derechos/deberes, el ejercicio de aquella puede resultar impracticable. Vid. G. ARIÑo ORTnz, Economía y Estado. Crisis y reforma del sector público, Marcial Pons, Madrid, 1993, págs. 67-68, y «Libertad, propiedad y empresa», La empresa en la Constitución Española, Aranzadi, Pamplona, 1989, pág. 111; A. Roso, «Actividad económica pública y actividad económica privada en la Constitución española», Revista de Derecho Mercantil, núm. 169, 1983, págs. 387 y ss.; F. REY MARTÍNEZ, La propiedad privada en la Constitución Española, CEC, Madrid, 1995, pág. 328.

33 Así lo considera J. E. SORIANo, vid. Hacia la tercera desamortización..., cit., pág. 82.

34 Vid. «Derecho de propiedad...», cit., pág. 96. En términos muy similares, S. Muñoz MaChado considera que la libertad de empresa sólo puede ser objeto de legítima intervención o restricción cuando exista un fin de interés público que lo justifique y cuando se trate de medidas adecuadas para la consecución de semejante fin, esto es cuando respeten el principio de proporcionalidad. Vid. "Libertad de empresa y unidad de mercado», La empresa en la Constitución Española, Aranzadi, Pamplona, 1989. pág. 215.

Cfr. la Exposición de Motivos de la LS90, apartado I, párrafo primero. 
RERLEXIONES CRÍICAS EN TORNO A LA STC 61/1997, ...

curría la LS90, hoy el TR92, al no indemnizar a quienes tras la nueva publicatio pasaban a verse privados ablatoriamente de derechos o facultades dominicales hasta el momento legalmente reconocidos. Como hemos indicado, con esta Ley se establece una limitación general al derecho de propiedad privada sobre el suelo, en cuya virtud las facultades urbanísticas de urbanizar y edificar en forma urbana quedan excluidas de su contenido y de su función social. Esta nueva limitación no afectaría inmediatamente a los propietarios de suelo rústico o no urbanizable pues ya estaban privados de facto de tal facultad mientras no se cambiare su calificación. No ocurriría igual con los propietarios de suelo urbano o urbanizable para los que esta nueva previsión sí suponía la directa privación de lo que hasta el momento constituía elemento integrante de su derecho de propiedad.

También aluden los recurrentes a la supuesta violación por esta misma norma de la otra garantía constitucional del derecho de propiedad privada: la reserva de ley. El artículo 2 de esta Ley - hoy, artículo 8 TR92-, manteniendo el sentido de anteriores redacciones —artículos 70 de la LS56 y 76 del TR76-, otorgó importantes facultades a la Administración para configurar la propiedad por medio de la aprobación de planes: «La utilización del suelo y, en especial, su urbanización y edificación, deberá producirse en la forma y con las limitaciones que establezcan la legislación de ordenación territorial y urbanística y, por remisión de ella el planeamiento, de conformidad con la clasificación y calificación urbanística de los predios».

Ciertamente, ya desde 1956 la Ley no ha sido el acto jurídico que ha delimitado en soledad el contenido del derecho a la propiedad, sino que, por remisión de ella, lo han hecho también unas normas de carácter meramente administrativo: los planes. La aceptación de lo que se denominó «concepción estatutaria» de la propiedad del suelo llevó a que la Ley del Suelo, en su papel de norma abstracta y general, efectuase un explícito llamamiento a los planes para que éstos concretasen el contenido del derecho de propiedad, esto es, las facultades y deberes de los propietarios para cada clase de suelo y para cada momento.

Esta situación, que no pudo realmente cuestionarse en cuanto a su coherencia con el sistema anterior a la entrada en vigor de la Constitución ${ }^{36}$, es ahora

36 La relación de esta práctica «delegativa» de las Leyes del Suelo preconstitucionales hacia los planes urbanísticos con el sistema jurídico entonces vigente ha sido explicada por J. M. BOQUERA OLIVER en los términos siguientes: «a partir de 1956 fue posible, en virtud de la Ley del Suelo, que los planes de urbanismo limitasen a la propiedad privada, porque el Código Civil, una ley, reservaba su limitación a la ley, pero la Ley del Suelo, posterior al Código Civil, permitía a los planes - reglamentos- limitar la propiedad urbanística». Esto acontecía, aun cuando lo que por aquel entonces hacía las veces de ley fundamental o constitucional, esto es, el Fuero de los Españoles de 1945, consagrara en sus artículos 30 y 34, una reserva a la ley como reguladora de la propiedad privada, pues «no existían instancias judiciales para ha- 
REALA 274-275 (MAYO-DICIEMBRE, 1997)

sometida al juicio del Tribunal Constitucional por los citados recurrentes al considerarla incompatible con la reserva que la Constitución efectúa a la Ley para la regulación del derecho de propiedad en sus artículos 33.2, 33.3, y sobre todo, en el $53.1 \mathrm{CE}^{37}$.

\section{El porqué de su exclusión del fallo: la discutible caducidad de los recursos contra la Ley de 1990}

Con un más que dudoso respeto del principio de congruencia y motivación comunes a la función jurisdiccional, en el fallo de la sentencia el Tribunal Constitucional ha aludido a la existencia de estas impugnaciones, pero no se ha pronunciado sobre su contenido impugnatorio. La derogación en su totalidad de la LS 90 por el TR92 ${ }^{38}$ y el carácter abstracto de esta clase de recursos han sido las causas por las que el Tribunal Constitucional ha considerado extinguido el objeto del proceso «en punto a las escasas pretensiones materiales o sustantivas que algunos recurrentes dedujeron frente a la Ley $8 / 1990 »{ }^{39}$ y por lo que estas imprecisas y genéricas impugnaciones no han obtenido respuesta de fondo. El Alto Tribunal reduce así el proceso a la resolución de un conflicto competencial originado por la diferente calificación normativa otorgada por el legislador estatal a los preceptos del Texto Refundido de la legislación urbanística, sin que, en ningún caso, se refiera a los derechos y las libertades de los ciudadanos ${ }^{40}$.

Pero, esta supuesta desaparición del objeto de los recursos de inconstitucionalidad deducidos contra la LS90 es más que discutible. Así, la pronta derogación de la LS90 por el TR92 no anula el que, durante su corto período de existencia, se produjeran determinados hechos amparados en su vigencia y no propiamente en la del Texto que la refunde. De igual manera, no parece haber reparado el Alto Tribunal en que el núcleo fundamental de la impugnación —esto es, la determinación del régimen de aplicación de la Ley estatal- provenía de la calificación que la LS90 otorgó a unos preceptos que pasaron posteriormen-

cer efectiva la superioridad de la ley fundamental sobre la ordinaria». Cfr. «La limitación de la propiedad...», cit., págs. 45 y ss.

37 Vid. J. L. MARTtinez LópeZ-MuÑIz, «Derecho de propiedad...», cit., pág. 82. Para un análisis más detallado vid. el estudio monográfico de F. REY MARTINEz, La propiedad privada..,, cit., págs. 412 a 438.

$38 C f r$. Disposición derogatoria única, apartado $10^{\circ}$ del TR92.

39

Cfr. STC 61/1997, f.j. 3.

40 Así se desprende del fundamento jurídico 12: «lo que los recurrentes impugnan del TR92 no es, propiamente, su articulado sino la calificación otorgada por la Disposición Final Única de la Ley a los diversos preceptos de la misma, esto es, el tipo de título competencial (básico) y el régimen de aplicabilidad (plena y supletoria)». 
REFLEXIONES CRITICAS EN TORNO A LA STC 61/1997....

te al TR92, estando, por tanto, el origen de la controversia en la LS90. Tampoco parece haber advertido que hubo una serie de preceptos de la LS90 impugnados por motivos competenciales que al no ser posteriormente incluidos en los recursos interpuestos contra el TR92 no han obtenido respuesta ${ }^{41}$, y que, por tanto, el enjuiciamiento de las impugnaciones relativas al TR92 no resuelve todas las cuestiones en torno a la ley delegante, tal y como manifestó el propio Tribunal (f.j. 3, párrafo cuarto in fine). Tampoco la derogación de la LS90 ha extinguido los problemas de constitucionalidad material que contra esta norma fueron alegados porque, como veremos, éstos son igualmente predicables del TR92 al reproducir su articulado el contenido de gran parte de la LS90. Además, por último, pese a esa derogación, la LS90 sigue aún aplicándose a raíz de las invocaciones que el parcialmente vigente TR92 continúa aún realizando a esta norma ${ }^{42}$.

\section{Vias abiertas para su planteamiento}

Como vemos, la limitación del enjuiciamiento de constitucionalidad a la resolución de las impugnaciones presentadas contra el TR92 ha supuesto, por lo que ahora nos interesa, la imposibilidad de un pronunciamiento por motivos diferentes a los estrictamente competenciales. El TR92 no fue impugnado por una posible violación a los derechos y libertades del individuo que la Constitución reconoce, a pesar de que su articulado reproducía el contenido de aquellos preceptos de la LS90 que motivaron una reclamación de inconstitucionalidad material. Esta incompleta resolución de las reclamaciones hace que aún subsistan motivos por los que impugnar materialmente la vigente legislación urbanística estatal y medios procesales —aunque sólo sea en sentido hipotético- por los que obtener una respuesta de fondo del Tribunal Constitucional sobre éstas $\mathrm{u}$ otras cuestiones. Recordemos éstos, aunque se trate de algo obvio.

\section{a) La cuestión de inconstitucionalidad}

Efectivamente, pese a la derogación de la LS90, hoy esas impugnaciones materiales de que tal norma fue objeto hace casi siete años, podrían volver a constituir el objeto de un proceso constitucional. $\mathrm{Y}$ es que esa profunda refor-

41 Se trata de los artículos 11, 12, 14, 15.1, 20 y 74.1 LS90 (equivalentes a los artículos 23.1, 24, 25, 26, 33.1 y 218 TR92) impugnados por la Junta de Castilla y León entre otros; y del artículo 21 LS90 (equivalente al artículo 240 TR92) impugnado por el Parlamento de Navarra. Vid. A. ORTEGA GaRcla, Derecho Urbanistico..., cit., pág. 19.

42 Así ocurre con la vigente Disposición Transitoria 5., apartado primero, en la que se regula el régimen de «las edificaciones existentes a la entrada en vigor de la Ley $8 / 1990$, de 25 de julio». A esta cuestión se ha referido también A. ORTEGA GARClA, Derecho Urbanístico..., cit., págs. 18-19. 
ma que la LS90 introdujo en el régimen urbanístico de la propiedad del suelo (artículos 1 a 28 LS90) fue incorporada en su integridad al articulado del TR92 (artículos 5 a 41 TR92) y continúa, tras la STC 61/1997, vigente prácticamente en su totalidad, gracias, probablemente, a esa falta de resolución de los recursos presentados contra la LS90.

Así, y limitándonos a los aspectos más relevantes del citado régimen, mantienen su vigencia, entre otros, los siguientes preceptos del TR92:

- el artículo 5, por el que las facultades de contenido urbanístico se desgajan del contenido inherente del derecho de propiedad para convertirse en algo susceptible de adquisición, tal y como había consagrado ya el artículo 1 de la LS90;

- los artículos 6 y 7 consagradores, respectivamente, del principio general de no indemnizabilidad por la ordenación del uso de los terrenos y construcciones, y de los principios de participación de la comunidad en las plusvalías generadas por la acción urbanística de los entes públicos y de reparto de beneficios y cargas entre los afectados conforme a las previsiones de la Ley (tomados ambos principios de los artículos 3 y 4 de la LS90 que a su vez reflejaban las previsiones del artículo 87.1 del TR76 y del artículo 70.1 y 3 de la Ley del Suelo de 1956);

- el artículo 19, por el que la incorporación al proceso urbanizador y al edificatorio de acuerdo con el planeamiento o legislación urbanística aplicable no es sólo un derecho, sino un auténtico deber de los propietarios afectados que nace con la aprobación del planeamiento preciso (reproducción literal del artículo 8 LS90);

- el artículo 20, en el que se enumeran los diferentes deberes legales cuyo cumplimiento condiciona la adquisición gradual de facultades en sentido casi idéntico a como lo previó el artículo 9 LS90;

- el artículo 23 que reproduce el principio consagrado por el artículo 11 LS90 conforme al cual, el contenido urbanístico de la propiedad inmobiliaria se integra, mediante la adquisición sucesiva de los derechos a urbanizar, al aprovechamiento urbanístico, a edificar y a la edificación;

- y, en fin, los artículos 24.1 .3 y 4, 26, 28.1 y 5,33 y 37, en los que se fijan los distintos requisitos para la adquisición de los referidos «derechos-deberes» (traslación textual de los artículos 12, 15, 20 y 25 LS90); y los artículos 25, 35.2, 38.1, 40.1 y 2, y 41 reguladores de las diferentes consecuencias o «sanciones» que puede acarrear el incumplimiento de 
REFLEXIONES CRITICAS EN TORNO A LA STC 61/1997...

los referidos deberes (tomados igualmente de lo ya establecido por la LS90 en sus artículos $14,23.2,26.1,27.1$ y 2 , y 28 ).

Frente al contenido de esta regulación no cabría evidentemente ya la interposición de un nuevo recurso de inconstitucionalidad por haber transcurrido el plazo legalmente establecido para ello ${ }^{43}$. Pero de nuevo podría ser objeto de un juicio de constitucionalidad en el hipotético supuesto de que un juez o tribunal planteasen, en un proceso abierto con motivo de la aplicación del TR92, una cuestión de inconstitucionalidad ante el Tribunal Constitucional por entender que tales preceptos, de cuya validez tuviese que depender el fallo, es contraria a la Constitución ${ }^{44}$, por violación de esas mismas normas constitucionales (artículos 33,38 y $14 \mathrm{CE}$ ) a las que hace siete años se referían las citadas Comunidades Autónomas.

\section{b) La cuestión interna o autocuestión de inconstitucionalidad}

De igual modo, y en términos todavía más hipotéticos, la referida incompatibilidad de ciertos postulados de la vigente Ley del Suelo (TR92) con determinados principios y derechos constitucionales podría originar - de nuevo, por no haberse pronunciado ya el Alto Tribunal- un enjuiciamiento sobre su constitucionalidad material a través de la denominada «autocuestión de inconstitucionalidad» o «cuestión interna de inconstitucionalidad».

Por este nuevo cauce, sólo se podría llegar al citado control de la constitucionalidad del TR92 en el supuesto de que, estimado un recurso de amparo interpuesto contra la misma por lesionar su aplicación, por ejemplo, el principio de igualdad, la Sala del Tribunal decidiese elevar la cuestión al Pleno «que podrá declarar la inconstitucionalidad de dicha ley» (artículo 55.2 LOTC).

Si el TR92 incurriera en violación de un derecho fundamental o libertad pública incardinados en alguno de los artículos 14 a 30 de la Constitución —en la práctica sólo cabría en relación con el artículo 14-, podría ser objeto de un recurso de amparo que, de ser finalmente estimado por la Sala del Tribunal, dejaría abierta esa vía anteriormente señalada para que el Pleno declarase, en su caso, la inconstitucionalidad de dicha Ley.

Esta opción, y dado que nuestro sistema no admite un recurso de amparo directo contra leyes, sólo sería viable cuando, la lesión del derecho fundamental

43 Conforme al artículo 33 LOTC «el recurso de inconstitucionalidad se formulará dentro del plazo de tres meses a partir de la publicación de la Ley, disposición o acto con fuerza de Ley impugnado ...».

44 Vid. el artículo 163 CE y 35 a 38 de la LOTC. 
tuviese su origen en la propia Ley del Suelo y el órgano judicial obligado a aplicarla no hubiese podido repararla per $\mathrm{se}^{45}$.

¿Podría dar lugar a semejante situación la aplicación del TR92? Ya hemos visto que la LS90 fue impugnada mediante un recurso de inconstitucionalidad por violación del derecho a la igualdad reconocido en el artículo $14 \mathrm{CE}$ en que incurría el nuevo régimen de la propiedad del suelo. Idéntica impugnación podría plantearse contra el TR92 por mantener las mismas previsiones que la refundida LS90.

Retomando la línea argumental inicial, la hipotética estimación de tan imprevisible recurso de amparo permitiría finalmente un enjuiciamiento directo de la constitucionalidad del TR92 por nuevos motivos no competenciales a través de la comentada vía del artículo 55.2 LOTC.

En definitiva, la limitación del fallo a la resolución de cuestiones competenciales conlleva la pervivencia de problemas de constitucionalidad material en la actual legislación urbanística estatal y la existencia de medios procesales para resolverlos. El pronunciamiento del Tribunal Constitucional sobre estas cuestiones aquí apuntadas serviría para aclarar otros puntos sobre nuestro sistema urbanístico tan conflictivos como lo han sido los problemas competenciales hoy ya esclarecidos.

Es cierto que la argumentación principal y casi exclusiva que sustentaba todos los recursos presentados por las diferentes Comunidades Autónomas giraba en torno a la invasión por el Estado de las competencias de dichas Comunidades en la materia. Sin embargo, como ya hemos advertido, no eran éstas las únicas incógnitas que cuestionaban la aplicación de la legislación urbanística estatal. Además, la ausencia de determinación de lo que puedan ser las bases constitucionales de la política urbanística afecta también a la futura normativa urbanística estatal - hoy en trámites de aprobación- que, pese a respetar los criterios ya clarificados de reparto competencial, podría ser objeto de nuevas impugnaciones por no respetar el contenido material de la Constitución ${ }^{46}$.

45 Sobre este mecanismo vid. F. CAAMAÑo DOMfNGUEZ et al., Jurisdicción y procesos constitucionales, Mc Graw Hill, Madrid, 1997, págs. 125 y ss.

46 Como hemos visto aulteriormente (vid. supra nota 8), este proyecto de Ley reproduce parte del contenido de la actual legislación estatal. Así, por ejemplo, en su artículo 2 mantiene la misma remisión al planeamiento para la regulación del derecho de propiedad sobre el suelo, poco acorde con la reserva legal constitucional. De este modo, las impugnaciones ya presentadas contra ésta y no resueltas podrían volver a ser deducidas en similares términos contra lo que finalmente constituya la futura Ley del Suelo estatal. Esta situación dotaría a esta normativa nuevamente de una cierta inseguridad jurídica imputable en gran medida al proceder del Tribunal Constitucional. 
REFLEXIONES CRITICAS EN TORNO A LA STC 61/1997...

\section{C) Impugnaciones formales no competenciales pendientes de resolución}

Frente a lo que ocurrió con la LS90, el TR92 no fue objeto de impugnación alguna por violación de derechos o principios constitucionales, sino únicamente por problemas de validez formal. De las seis Comunidades Autónomas que recurrieron la LS90 sólo dos - Cataluña y Aragón - reprodujeron sus impugnaciones contra el TR92 y por los mismos motivos competenciales por los que recurrieron la LS90. El tercero de los recursos presentados contra el TR92 -interpuesto, como sabemos, por el Consejo de Gobierno de la Comunidad Autónoma de las Islas Baleares-, también se fundaba en la supuesta invasión por el legislador estatal de su ámbito competencial exclusivo, sin que se añadieran a tales reclamaciones motivos de inconstitucionalidad material. Pero este ente autonómico se distinguió con respecto a los otros dos recurrentes por incorporar alegaciones de carácter igualmente formales, aunque no competenciales. Su recurso de inconstitucionalidad contra la globalidad del TR92 se basaba también en que infringía por diferentes motivos el artículo 82 de la Constitución regulador del ejercicio de la delegación legislativa.

A pesar de ser muchos los problemas de delegación legislativa detectables en este Texto Refundido, ésta fue la única Comunidad Autónoma que hizo alusión a semejante cuestión. Dos fueron, en concreto, las cuestiones planteadas:

- por un lado, se denunciaba la inconstitucionalidad en que incurrió el legislador delegante al emplear una Ley de Presupuestos para renovar el plazo otorgado al Gobierno para refundir la legislación urbanística estatal, por estimar que esta práctica violaba los límites materiales de tal clase de leyes $^{47}$;

- por otro lado, alegó también ciertos excesos en que incurría el Gobierno refundidor en el concreto ejercicio de la delegación legislativa. En particular, este exceso fue expresamente alegado en relación con el artículo 11.4 TR92 que, al equiparar con carácter general el suelo apto para urbanizar con el urbanizable programado, sobrepasaba, a juicio del recurrente, la habilitación conferida al refundidor al no ser ésta la regulación que había previsto la LS90.

Esta doble impugnación tampoco ha sido totalmente atendida por el Alto Tribunal. Sí se ha pronunciado en relación con la validez de la prórroga $\longrightarrow$ me-

47 La Disposición Final segunda de la LS90 habilitó al Gobierno para que, en el plazo de un año desde la publicación de aquélla, aprobara «un Texto Refundido de las disposiciones estatales vigentes sobre suelo y ordenación urbanay. Transcurrido este plazo sin que el Gobierno hubiera podido finalizar este cometido, el legislador optó por renovarle su habilitación acudiendo para ello a la Ley $31 / 1991$, de 30 de diciembre, de Presupuestos Generales del Estado para 1992, a través de su Disposición Final 5.: 
jor quizás renovación - del plazo concedido para acometer la refundición encomendada a través de una Ley de Presupuestos ${ }^{48}$. Pero, respecto al posible ejercicio defectuoso de la delegación legislativa no ha existido juicio de fondo. De nuevo, es el petitum de la demanda lo que impide al Tribunal Constitucional pronunciarse sobre tal extremo en cuanto éste quedaba limitado, a su juicio, a la resolución de un conflicto competencial.

El aludido artículo 11.4 era sólo un ejemplo de los muchos existentes que podían haberse impugnado por violación de los límites constitucionales reguladores de esta clase de delegación legislativa (artículos 82 a $85 \mathrm{CE}$ ). Así, y partiendo de que el Gobierno fue habilitado no sólo para refundir la legislación estatal vigente en la materia, sino para, además, «regularizarla, armonizarla y aclararla», el ejercicio por el Gobierno de la delegación legislativa adoleció de ciertos excesos así como de algunas carencias.

Aunque no podamos analizar en profundidad estos problemas, en el TR92 hubo supuestos poco acordes con el significado constitucional de esta técnica

\footnotetext{
48 A este respecto, el Tribunal Constitucional ha respaldado la constitucionalidad de este cauce por considerar que la citada Disposición Final 5." de la Ley 31/1991 de Presupuestos Generales no es "una disposición que por sí misma contenga una regulación material, sino una Disposición Final [...] en la que se contiene, con una técnica ciertamente peculiar, la fijación de un nuevo plazo de la delegación legislativa al Gobierno para elaborar un Texto Refundido" y porque «lejos de producir inseguridad jurídica, ha servido a este principio constitucional, en cuanto habilita al Gobierno para reducir a unidad las sucesivas reformas legales». Cfr. f.j. 2 STC 61/1997.

Como se indica en el voto particular a esta sentencia (formulado por el Magistrado D. Manuel Jiménez de Parga y Cabrera), el Tribunal Constitucional se aparta notablemente con este nuevo parecer de la doctrina que al respecto había formulado en anteriores pronunciamientos. En concreto, se aparta del criterio expuesto en la STC 76/1992, de 14 de mayo, conforme al cual «para que la regulación por una Ley de Presupuestos, de una materia distinta a su núcleo mínimo, necesario e indisponible (previsión de ingresos y habilitación de gastos) sea constitucionalmente legítima es necesario que esa materia tenga relación directa con los gastos e ingresos que integran el Presupuesto [...]». Pese a que no se cumplían en esta ocasión ninguno de estos requisitos, el Alto Tribunal ha avalado la constitucionalidad de esta Disposición con el propósito probablemente, de poder entrar en el fondo de las impugnaciones planteadas pues admitir la inconstitucionalidad de la citada Disposición habría conllevado declarar la nulidad de todo el TR92 por haberse aprobado careciendo del presupuesto esencial habilitante exigido por el artículo 82.2 CE: la habilitación previa por Ley ordinaria aprobada por las Cortes Generales.

Pero, al margen de semejante propósito, a nuestro juicio, las Cortes Generales no emplearon un cauce constitucionalmente legítimo para renovar el mandato de refundición de la legislación del suelo. En este sentido, el recurso a una Ley de Presupuestos Generales, además de no respetar los límites constitucionalmente establecidos al contenido material de estas Leyes —previsión de ingresos y habilitación de gastos-. difícilmente puede entenderse compatible con el principio de seguridad jurídica que garantiza nuestra Constitución en su artículo 9.3 pues, en contra de esta previsión, se genera la inseguridad de que ya no toda disposición por irrelevante que sea, como en este caso, vaya a estar ad futurum comprendida en la Ley que le corresponda según la materia que regule cuando, precisamente, fue la salvaguarda de tal principio lo que condujo al Tribunal Constitucional a exigir que «una Ley de contenido constitucionalmente definido, como es la Ley de Presupuestos Generales, no contenga más disposiciones que las que correspondan a su función constitucional» (STC 76/1992, f.j. 4..$^{\circ}$ ).
} 
legislativa. Entre las irregularidades o anomalías detectables cabe citar supuestos de la siguiente envergadura: a) la incorporación al articulado del TR92 de preceptos provenientes de los diferentes Reglamentos urbanísticos sin que de la Ley delegante se dedujera con entera nitidez la habilitación al Gobierno para elevar y congelar el rango de tales preceptos ${ }^{49}$; b) la introducción de cambios sustanciales modificadores del sentido originario de los preceptos que el Gobierno refundía ${ }^{50}$; c) la regulación ex novo de determinadas materias sobre las que nada había previsto el legislador de la normativa a refundir ${ }^{51}$; d) la existencia de artículos cuyo contenido había sido derogado por el legislador en fechas anteriores al mandato de refundición ${ }^{52} ; \mathrm{y}$, por último, e) la omisión de disposi-

\begin{abstract}
49 A este respecto, hubo más de 40 artículos en el TR92 que reproducían total o parcialmente el contenido de diversos preceptos de los distintos reglamentos urbanísticos. A título de ejemplo, los artículos 72. 5 a 84 -hoy inconstitucionales- recogían casi literalmente las previsiones de los artículos 41,43 , $44,45,71.1,72.1,74.1,76,88.1$ y $3,89,90,91,92,93,95,96,97$ y 102 del Reglamento de Planeamiento Urbanístico, de 23 de junio de 1978. Para un estudio más detallado sobre este aspecto puntual vid. A. Ortega García, Derecho Urbanístico..., cit., pág. 61, y J. R. Fernández TorRes, «Refundición y Constitución: examen del Texto Refundido de la Ley sobre Régimen del Suelo y Ordenación Urbana de 26 de junio de 1992», RAP, núm. 131, 1993, págs. 127-136; y el Dictamen del Consejo de Estado núm. 648/1992, cit., págs. 21-52.
\end{abstract}

so A esta cuestión se han referido más pormenorizadamente A. GALlEGo ANABTTARTE, «Régimen juridico de la propiedad del suelo. Valoraciones. Expropiaciones y venta forzosa», $R D U$, núm. 134, 1993, pág. 45; J. A. Ramos Medrano y M. P. Ramos MEDRANO, «La pretendida deslegalización del régimen jurídico de fuera de ordenación», RDU, núm. 148, 1996, págs. 105-106; J. R. FERNÁNDEZ TORRES, «Refundición y Constitución...», cit., págs. 136-146; F. PERALES MADUEÑo, «El nuevo Texto Refundido...», cit., págs. 51-52; A. MEnÉndez ReXACH, «La Ley 8/1990, de 25 de julio», Cuadernos de Derecho Judicial (Urbanismo), Madrid, CGPJ, 1992, pág. 142; y J. A. CHINCHILLA, «Régimen urbanístico de la propiedad del suelo», $R D U$, núm. 152, 1997, págs. 73-75.

Sobre este tema ha habido también pronunciamientos jurisprudenciales en diferentes sentidos; así, vid. Sentencias del Tribunal Superior de Justicia de Castilla y León (Sala de Burgos) de 31 de mayo de 1995 (Ponente López-Muñiz Goñi, Recurso 1369/1994), de 9 de noviembre de 1994 (Ponente Baltasar Rodríguez, Recurso 1241/1993), y de 23 de diciembre de 1994 (Ponente Izquierdo Peraita, Recurso 423/1994); y la Sentencia del Tribunal Superior de Justicia de Andalucia (Sala de Málaga) de 10 de septiembre de 1994.

51 Vid. MARTINEz-CARDós Ruiz, «Un caso de extralimitación en la potestad refundidora: la revisión de oficio de acuerdos municipales por subrogación en materia urbanística», $R D U$, núm. 142, 1995. págs. 13 y ss; J. A. RAMOS MEDRANO y M. P. RAMOS MEDRANO, «La pretendida deslegalización...", cit., pág. 105; J. R. FernÁNDEZ TORRES, «Refundición y Constitución...», cit., págs. 147-154; F. Perales MAdueño, «El nuevo Texto Refundido...» cit., págs. 42-57; y A. Gallego ANABrtaRTE, «Aspectos generales de la refundición de la legislación urbanística, objeto y límites de la tarea refundidora», $L a$ reforma del Régimen Urbanístico y de la Ordenación Urbana, CEMCI, Granada, 1994, págs. 17-18.

52 La habilitación al órgano refundidor para regularizar, aclarar o armonizar un conjunto de disposiciones normativas integra la facultad de suprimir aquellos preceptos ya derogados a la fecha de la refundición. Vid. por todos, J. A. Santamarla PASTOR, Fundamentos de Derecho Administrativo, Centro de Estudios Ramón Areces, Madrid, 1988, pág. 663-665; y T. DE LA QUADRA-SALCEDO, «La delegación legislativa en la Constitución», Estudios sobre la Constitución Española (Libro-homenaje al Prof. $E$. García de Enterría), Civitas, Madrid, 1991, págs. 365-368. 
REALA 274-275 (MAYO-DICIEMBRE, 1997)

ciones sustantivas que, formando parte de los textos objeto de refundición, no fueron incluidos por el Gobierno en el articulado del TR92 ${ }^{53}$.

Por fortuna, la aplicación del contenido sustantivo de la sentencia ha supuesto la eliminación de gran parte de los preceptos que, por unos u otros motivos de los arriba enumerados, no se adecuaban a las previsiones constitucionales reguladoras de los Decretos Legislativos (artículos 82 a $85 \mathrm{CE}$ ). Sin embargo, aún quedan algunos artículos vigentes sobre los que debería efectuarse un juicio de constitucionalidad, en este caso por una posible violación del artículo 82 $\mathrm{CE}$, en cuanto se ha producido un ejercicio extralimitado de la potestad delegada. En este supuesto se encuentran hoy, entre otros, los siguientes preceptos del TR92:

a) el artículo 16.4 TR92 sobre prohibiciones y autorizaciones en el suelo no urbanizable. Este precepto extiende a esta clase de suelo una serie de requisitos necesarios para proceder a la autorización e inscripción en el Registro de la Propiedad de las escrituras de declaración de obra nueva que la normativa objeto de refundición —en este caso la LS90- sólo había previsto para las edificaciones realizadas en terrenos clasificados como suelo urbano y urbanizable ${ }^{54}$;

Pese a ello, en el caso de la legislación que ahora nos ocupa, el Gobierno no expulsó de la normativa que refundía preceptos que, en fechas bastante anteriores a la aprobación del TR92, habían dejado ya de formar parte de nuestro ordenamiento jurídico. A ello se ha referido J. L. MARTínez-CARDós RuIz, «Un caso de extralimitación...», cit., págs. 13 y ss.

53 La redacción del articulado del TR92 contó también con la omisión de párrafos o incisos esenciales de los textos objeto de refundición que terminaron por implantar una regulación jurídica manifiestamente divergente a la establecida por el legislador de origen. Vid. al respecto T. R. FERNÁNDEZ RODRíGUEZ, Manual de Derecho Urbanistico, El Consultor, Madrid, 1993, 10." ed., pág. 200; y J. R. FERNÁNDEZ TORRES, «Refundición y Constitución...», cit., págs. 154-158.

54 Con la aprobación de la LS90, la autorización e inscripción en el Registro de la Propiedad de las escrituras de declaración de obra nueva quedaban sujetas al cumplimiento de una pluralidad variada de requisitos: acreditación del otorgamiento de preceptiva licencia de edificación; expedición por técnico de la certificación de finalización de la obra conforme a proyecto aprobado; etc. (artículo 25 LS90). Aunque el precepto no lo dijera expresamente, cabía deducir por su ubicación sistemática que se estaba refiriendo a las edificaciones realizadas en terrenos clasificados como suelo urbano y urbanizable.

Al incorporarse este precepto al Texto refundido, el Gobierno respetó fielmente la anterior regulación tal y como refleja el artículo 37.2 TR92, en el que, de nuevo, por su ubicación en el Capítulo III del Título I del TR92 relativo al "régimen del suelo urbano y urbanizable», cabía considerar que era en esta clase de terrenos en los que tenía aplicación.

Pero el refundidor extendió estas mismas exigencias a las edificaciones construidas en suelo no urbanizable (artículo 16.4 TR92) sin que, aparentemente, tal propagación respondiese a regularización, aclaración o armonización alguna de la LS90 con la anterior legislación, sino, al contrario, a la aplicación de un precepto de la LS90 a un supuesto diferente al allí previsto. La falta de habilitación para semejante innovación hace que este artículo, todavía en vigor, pueda incurrir en inconstitucionalidad por infracción de las normas constitucionales sobre la delegación legislativa (artículo $82 \mathrm{CE}$ ). Vid. J. R FERNÁNDEZ TORRES, «Refundición...», cit., pág. 147; y, F. PERALES MADUEÑo, «El nuevo Texto...», cit., pág. 57. 
b) el artículo 225.3 TR92 que, regulador de los supuestos de reversión de los terrenos expropiados, fija ex novo un plazo de diez años para que ésta pueda tener lugar «en los terrenos incluidos en una unidad de ejecución para su desarrollo por el sistema de expropiación» ${ }^{\text {ss; }}$

c) y todos aquellos preceptos que reproducen el contenido de preceptos reglamentarios. De los más de cuarenta artículos que el TR92 tomó literalmente de los Reglamentos urbanísticos ${ }^{56}$, aún conservan vigencia los siguientes: el artículo 47 a) relativo al momento en que han de referirse las valoraciones (reproducción del 136 a) del RGU); 168.1 y 2 sobre los efectos del acuerdo aprobatorio de la reparcelación (reproducción de los artículos 122.3, 123.1 y 2 y 99 , en relación con el 98 del RGU); 219 regulador de los supuestos a los que se aplica el procedimiento de tasación conjunta (reproducción del artículo 202 del RGU); 220 relativo a la aprobación y efectos del procedimiento de tasación conjunta (reproducción del 203 del RGU); 223 referente a la ocupación de fincas e inscripción en el Registro (reproducción del 209 del RGU); 224 concerniente a la adquisición por la Administración de fincas libres de cargas (tomado del 210 del RGU); 232 en torno a la inscripción registral de la resolución de incumplimiento de deberes urbanísticos (tomado del artículo 27.1 y 2 del REF); 235.2 relativo igualmente a la inscripción registral (reproducción del artículo 38.2 del REF); 253.3 y 254.2 sobre las consecuencias de la anulación de licencias (que reproducen el sentido del artículo 35 del Reglamento de Disciplina Urbanística); y, en fin, el artículo 274 regulador de las infracciones constitutivas de delito o falta (tomado del 56 del RDU al que, además, modifica).

La perspectiva de vigencia indefinida de estos preceptos ante la falta actualmente de impugnación ante el Tribunal Constitucional, podría ser suplida por el pronunciamiento que en las próximas fechas pudiera efectuar el Tribunal Supremo al recurso presentado y pendiente de resolución con motivo, precisamente, de este comentado uso excesivo de la delegación legislativa.

\footnotetext{
55 En concreto, se aplica tal supuesto «cuando hubieren transcurrido diez años desde la expropiación sin que la urbanización se hubiera concluidon. En la legislación de origen, por el juego de los artículos 67.1 y 2 TR76 la reversión quedaba a expensas de lo que determinaran los Planes cuya vigencia es, en principio, indefinida (artículos 45 TR76 y 125 TR92). Esta previsión complicó ciertos aspectos del régimen jurídico de la reversión. Así, por ejemplo, si para su nacimiento era preciso el agotamiento de la eficacia de los Planes urbanísticos, no era sencillo determinar el momento a partir del cual computar el plazo para el ejercicio del derecho. Este y otros problemas quisieron solventarse por el refundidor a través de la fijación de ese plazo pero, ni el TR76, ni la LS90, ni tan siquiera la Ley de Expropiación Forzosa (artículos 54 y 55) amparan semejante novedad. Vid. J. R. FERNÁNDEZ TORRES, «Refundición...», cit., pág. 152.
}

Vid. supra nota 49. 
En todo caso, de nuevo siguen pendientes de resolución cuestiones que ya fueron planteadas ante el Tribunal Constitucional.

\section{SUPLETORIEDAD DEL DERECHO URBANÍSTICO ESTATAL: PROBLEMAS DE LA DISCUTIBLE LIMITACIÓN JURISPRUDENCIAL DE LA CLÁUSULA DEL ARTÍCULO 149.3 CE}

Uno de los aspectos más relevantes de esta sentencia, al tiempo que el más polémico, ha sido, sin duda, la eliminación de todos aquellos preceptos del TR92 que recibieron el calificativo de legislación supletoria aplicable en defecto de regulación específica por las Comunidades Autónomas» (Disposición Final Primera, apartado $3 .^{\circ}$ de la LS90 y Disposición Final Única, apartado $3 .^{\circ}$ del TR92). Esto ocurría principalmente con todos aquellos así calificados por la LS90 y con los artículos refundidos provenientes del TR76, la mayoría de los cuales se integraron en el TR92 con el calificativo de preceptos supletorios.

Entre los recurrentes, salvo Navarra, Castilla y León y las Islas Baleares, todos los demás impugnaron específicamente la citada Disposición Final - tanto de la LS90, como del TR92-, al considerar que el Estado carecía de legitimidad constitucional para dictar legislación supletoria en aquellas materias para las que no ostente título competencial específico, como es el caso del urbanismo ${ }^{57}$.

El Tribunal Constitucional, condicionado por sus propios pronunciamientos de fechas anteriores (fundamentalmente por el de la STC 118/1996, de 27 de junio, aunque también por el de la STC 147/1991) ${ }^{58}$, ha venido a dar la razón a

57 Vid. recurso núm. 2479/1990 [apartado a)] interpuesto por la Diputación Regional de Cantabria; recursos núms. 2481/1990 [apartado a)] y 2342/1992 [apartado d)] interpuestos ambos por la Generalidad de Cataluña; recursos núms. 2486/1990 [apartado e)] y 2341/1992 [apartado a)] interpuestos por la Diputación Regional de Aragón; y recurso núm. 2488/1990 [apartado a)] interpuesto por el Gobierno de Canarias.

58 Sucintamente expuesto, el giro interpretativo del Tribunal Constitucional en torno al artículo 149. 3 in fine de la Constitución comenzó fundamentalmente con su Sentencia 147/1991 por la que decidió reducir el concepto de supletoriedad al de una «función referida al conjunto del ordenamiento jurídico, cuyo valor supletorio debe obtenerse por el aplicador del Derecho a través de reglas de interpretación pertinentes, incluida la vía analógica, y no ser impuesta directamente por el legislador desde normas especialmente aprobadas con tal exclusivo propósito, para incidir en la reglamentación jurídica de sectores materiales en los que el Estado carece de todo título competencial que justifique dicha reglamentación» (f.j. 7). A raíz de esta interpretación, el Alto Tribunal consideró que debían declararse nulas aquellas normas dictadas por el Estado con el único proposito de aplicarse supletoriamente por las Comunidades Autónomas en materias atribuidas a la exclusiva competencia de éstas (f.j. 7).

Posteriormente, en la Sentencia 118/1996 añadio, sobre lo anterior, la consideración de que la supletoriedad no es un título competencial por lo que, tampoco en las materias en las que el Estado ostenta com- 
estas Comunidades Autónomas, limitando de manera importante la operatividad de la propia letra de la Constitución cuando reconoce, en el párrafo $3 .^{\circ}$ de su artículo 149, que «el Derecho estatal será, en todo caso, supletorio del Derecho de las Comunidades Autónomas».

Frente a esta inequívoca voluntad constitucional, la aplicación supletoria de la legislación estatal queda ahora sujeta al cumplimiento o a la concurrencia de una serie de requisitos no exigidos por el texto constitucional. Para que alguna de sus disposiciones pueda tener aplicación supletoria, deberá ser a partir de la invocación de «algún título específico que le habilite en concreto para establecer la reglamentación de que se trate» -es decir, invocando alguno de los títulos enumerados en el artículo 149.1 CE-, y siempre que así lo «infiera» el aplicador del Derecho autonómico ${ }^{59}$.

Es evidente que este precepto no tiene en la actualidad el mismo sentido y operatividad que pudo tener en el momento de dictarse la norma constitucional. En aquel entonces, la incertidumbre en torno a la efectiva instauración de los entes autonómicos de potestativa creación (artículo $137 \mathrm{CE}$ ) y el desconocimiento en torno a las competencias que podrían asumir y que efectivamente asumirían, convertían a la legislación estatal en la única existente y aplicable en la mayoría de los casos. Posteriormente, una vez constituidas las diferentes Comunidades Autónomas y definidas sus competencias propias, las previsiones de la legislación estatal comenzaban a cumplir, en aquellas materias de competencia autonómica «exclusiva», una función realmente supletoria en la medida en que sólo se aplicaban en los supuestos de inexistencia o de incompleta regulación por parte de la normativa autonómica. En tanto en cuanto no se proceda por todas y cada una de las Comunidades Autónomas a la elaboración de una normativa global -y no sólo parcial - reguladora de la totalidad de las materias sobre las que ostentan competencia «exclusiva», hoy, como en 1978, el Derecho estatal es imprescindiblemente supletorio del autonómico en cumplimiento de la propia previsión constitucional ${ }^{60}$.

petencias compartidas puede producir normas jurídicas meramente supletorias. De esta forma, la posible aplicación supletoria del Derecho estatal ha quedado en manos del aplicador del Derecho autonómico para el supuesto de que éste aprecie la presencia de una laguna no bastando la ausencia de regulación específica (ff.jj. 6 y 8).

Para un conocimiento más detallado de la evolución de la jurisprudencia del Tribunal Constitucional sobre esta materia vid. J. C. TEJEDOR BiELSA, «La necesaria reformulación del concepto de bases provocada por la STC 118/1996, de 27 de junio», Revista Aragonesa de Administración Pública, núm. 9, 1996, págs. 451-460.

59 Ambos extremos fueron expuestos ya en la STC 118/1996, ff.jj. 5 y 8, y son de nuevo reafirmados en el f.j. 12.c) de este fallo.

60 No es ésta la interpretación que sostiene el Tribunal Constitucional. En la citada STC 118/1996, afirmó que la supletoriedad sólo tuvo sentido en esa etapa de nacimiento del Estado de las Autonomías ante la 
Pero el Tribunal Constitucional con sus recientes pronunciamientos ha venido a inutilizar en gran medida la cláusula, impidiendo al Estado dictar nuevas normas meramente supletorias y adaptar así su legislación en lo que tiene de supletoria, a la evolución que se vaya produciendo del ordenamiento jurídico -en este caso, urbanístico- ${ }^{61}$. A nuestro juicio, detrás de esta interpretación jurisprudencial se esconde la errónea apreciación de que la legislación supletoria del Estado dictada ex artículo 149.3 CE en éste o en cualquier otro sector de idéntica configuración que el urbanístico, viene a limitar o, quizás, a condicionar las competencias legislativas de las Comunidades Autónomas, cuando, en realidad, las previsiones de tal legislación pueden ser desplazadas desde el mismo momento en que el ente autonómico disponga. $Y$ es que, queda $\longrightarrow$ quedaba- en manos del propio ente autonómico aceptar como aplicable a su recinto territorial las normas sectoriales supletoriamente elaboradas por el legislador estatal, o rechazarlas plenamente elaborando nuevas disposiciones de contenido total o parcialmente diferente. La norma supletoria es perfectamente desplazable por la Comunidad Autónoma en el momento y en los términos que tenga por conveniente ${ }^{62}$.

Por contra, la nueva interpretación obliga innecesariamente a los legisladores autonómicos a legislar, de momento, en materia urbanística, cuando éstos podían no haberlo hecho por estimar perfectamente satisfactorias para las necesidades de sus respectivos ámbitos territoriales las previsiones de la legislación estatal.

inexistencia de ordenamientos autonómicos. Sin embargo, como ha señalado J. BARNÉs VÁzQUEZ, el Tribunal Constitucional no demuestra que, superada ya tal fase, se hayan agotado realmente las funciones normativas no invasoras de la supletoriedad, ni que el artículo $149.3 \mathrm{CE}$ se reduzca, una vez satisfecha semejante función provisional, a una simple regla interpretativa. Cfr. «Una reflexión sobre la cláusula de supletoriedad del artículo $149.3 \mathrm{CE}$ a propósito de la STC 118/1996. ¿Disposición transitoria o posible instrumento de equilibrio? Normas supletorias como complemento indispensable de las bases, una hipótesis de máxima efectividad de las competencias estatales y autonómicas», REDA, núm. 93 , 1997, págs. 89-90.

61 Como ha señalado J. C. TEJEDOR BIELSA, a partir de la Sentencia 118/1996, el Tribunal Constitucional ha optado por reducir la cláusula de supletoriedad a «regla de aplicación del Derecho dirigida al operador jurídico indicándole el ordenamiento que ha de utilizar para colmar las lagunas existentes en los ordenamientos autonómicos. Ésta no actúa ya como regla competencial de eficacia limitada ni siquiera con carácter complementario de otros títulos del Estado». Cfr. «La necesaria reformulación...», cit., págs. 447-448.

62 En muy similares términos críticos se ha pronunciado recientemente E. GARClA DE ENTERRIA a propósito de esta incipiente jurisprudencia del Tribunal Constitucional sobre la cláusula de supletoriedad. Como señala este autor, y como hemos tratado de exponer, «al dictar Derecho con carácter de supletorio del Derecho autonómico el Estado no invade, condiciona, limita o desconoce competencia autonómica alguna [... I no priva a las Comunidades Autónomas de ninguna de sus competencias propias y las deja en plena libertad de eliminar con la máxima facilidad dicha legislación supletoria sin más que ejercer positivamente su propia competencia normativa de desarrollo». Cfr. "Una reflexión sobre la supletoriedad del Derecho del Estado respecto del de las Comunidades Autónomas», REDA, núm. 95, 1997, págs. 412 y 414. 
REFLEXIONES CRITICAS EN TORNO A LA STC 61/1997,...

Pero es que, además, conduce a una petrificación o fosilización para ciertos territorios de una parte del ordenamiento jurídico urbanístico. Por aplicación de esta sentencia, la legislación urbanística estatal vigente hoy en día ha quedado, como sabemos, básicamente constituida por la suma de una doble normativa: de una parte, por aquellos preceptos del TR92 no anulados por el fallo y sobre cuyo contenido el Estado tiene plena capacidad de disposición; y de otra, por todos aquellos del TR76 que han vuelto a recobrar su vigencia pero, en este caso, a perpetuidad pues, conforme a esta interpretación de la cláusula de supletoriedad, el legislador estatal no podía ni puede derogar el que era su propio Derecho urbanístico con anterioridad a la constitución de los órganos de poder de las Comunidades Autónomas ${ }^{63}$, y ello aunque con su potestad legislativa básica modifique su regulación principial, los criterios rectores fundamentales.

Es cierto que esta fosilización parcial de la legislación urbanística sólo afectará a aquellas Comunidades Autónomas que todavía carezcan de legislación específica en materia de urbanismo - situación en la que se encuentran hoy Extremadura y La Rioja-; o que, aun habiendo legislado, lo hayan hecho parcialmente - lo que acontece en todas las demás Comunidades Autónomas a excepción de Cataluña, Galicia y Navarra-; y, además, sólo en tanto en cuanto no aprueben una legislación específica y completa en la materia.

Sin embargo, existen algunos territorios de nuestra geografía que no cuentan con esta última posibilidad y donde esa petrificación es, en principio, irreversible. Los territorios de Ceuta y Melilla no poseen, conforme se desprende de sus recientemente aprobados Estatutos de Autonomía ${ }^{64}$, facultades legislativas ni en ésta, ni en ninguna otra materia sobre la que ostentan competencia ${ }^{65}$. Esta carencia de potestad legislativa - a la que se ha referido recientemente algún autor- ${ }^{66}$ va a suponer que ambos territorios se vean condenados a aplicar ad aeternum todos aquellos preceptos del TR76 que estén vigentes, y sobre los que el Estado ya nada puede alterar ni ahora ni nunca. No parece haber sido

63 Cfr. STC 61/1997, f.j. 12.

64 Leyes orgánicas $1 / 1995$, de 13 de marzo, del Estatuto de Autonomía de Ceuta; y 2/1995, de 13 de marzo, del Estatuto de Autonomía de Melilla.

65 Así se desprende del artículo 21 de ambos Estatutos de Autonomía, conforme al cual las competen. cias de estas dos ciudades en las diferentes materias relacionadas en el apartado $1 .^{\circ}$ del citado artículo -entre las que figuran «la ordenación del territorio, urbanismo y vivienda» - únicamente comprenden «las facultades de administración, inspección y sanción y, en los térninos que establezca la legislación general del Estado, el ejercicio de la potestad normativa reglamentaria».

66 Cfr. T. R. FERnÁndeZ Rodríguez, «El desconcertante presente...», cit., págs. 194-195; A. MENÉN. DEZ REXACH, «Las competencias del Estado y de las Comunidades Autónomas...», cit., págs. 43-44; y E. GARClA DE ENTERRIA, «Una reflexión sobre la supletoriedad del Derecho del Estado...», cit., págs. 409 y 413. 
consciente el Tribunal Constitucional del enorme perjuicio que para estos territorios pudiera suponer el tener que aplicar dentro de cinco, diez, cincuenta, o más años, una legislación que hoy cuenta ya con más de veinte años de antigüedad, que se dictó antes de la aprobación de nuestra Constitución y que, en ocasiones, no responde a ciertos postulados de la misma.

Por fortuna, una correcta lectura del Estatuto de Autonomía de ambas ciudades permitiría, a nuestro entender, solventar esta ilógica situación. Conforme al apartado segundo del artículo 21 de sendas normativas, la potestad reglamentaria de estos entes sólo podrá ser desarrollada «en los términos en que establezca la legislación general del Estado». De aquí se desprende no sólo la posibilidad de actualizar la normativa aplicable a estos territorios, sino la habilitación con que aún sigue contando el legislador estatal para dictar, en su caso, una Ley urbanística general (esto es, sobre todos los aspectos integrantes del urbanismo, incluidos los que, para el resto del territorio español, sólo corresponden a las Comunidades Autónomas tal y como se desprende de la reciente Sentencia 61/1997) y aunque sólo tuviera como destinatarios los territorios de Ceuta y Melilla ${ }^{67}$.

Por todos estos motivos, a nuestro juicio, esta interpretación del Tribunal Constitucional debería ser reconsiderada pues no se advierten razones suficientemente justificadas por las que sea necesario anular el sentido que aún puede seguir desempeñando este precepto del texto constitucional.

67 Al hilo precisamente de esta circustancia, E. GARCIA DE ENTERRtA se ha referido a «la competencia legislativa plena y universal, y no sólo básica que, por la mera invocación de los Estatutos de Autonomía de estas dos ciudades, tiene aún el Estado en una parte al menos del territorio nacional». Cfr. "Una reflexión sobre la supletoriedad del Derecho del Estado...», cit., pág. 413. 